\title{
Determinants of Consumer Complaining Behavior: A study based on telecommunication firms of Pakistan
}

\author{
Abdur Rehman \\ Department of Management Sciences, The Islamia University of Bahawalpur, Pakistan
}

\section{Basit Saeed}

Department of Management Sciences, The Islamia University of Bahawalpur, Pakistan

Hina Kanwal

Department of Management Sciences, The Islamia University of Bahawalpur, Pakistan

\section{Muhammad Rizwan}

Lecturer, Department of Management Sciences

The Islamia University of Bahawalpur, Pakistan

E-mail: rizwan.arshad@iub.edu.pk

Muhammad Rehan

Department of Management Sciences, The Islamia University of Bahawalpur, Pakistan

\section{Shoaib Hassan}

Department of Management Sciences, The Islamia University of Bahawalpur, Pakistan

DOI:10.5296/ ijld.v3i6.6208 URL: http://dx.doi.org/10.5296/ ijld.v3i6.6208

\begin{abstract}
Due to the intense competition, the study of dissatisfaction among costumers has become the focus point of many firms. Hence this study focuses on consumer complaining intention keeping. Telecommunication firms have been kept in focus and descriptive research was conducted. The results show that attitude towards complaining, perceived possibility of success, subjective norms, all show significant effect on complaining intention and keeping
\end{abstract}


previous experience as a antecedent excluding subjective norms. The research can give a deep insight to telecommunication firms for managing dissatisfaction.

Keywords: Complaining Intention, Attitude towards complaining, Previous Experience

\section{Introduction}

Attention towards field of customer's behavior to complain is increasing to study the possible impact it has on consumer's forthcoming intention to buy the product or service again, their devotion towards a brand, the retrieval tactics of organizations to regain customers, and Diffusion of grapevine from these kind of complains .

With an atmosphere of intense war between products and kinds of sales channels it is very important to recognize the causes and consequences of this type of consumer behavior (Kim et al., 2003). Additionally, this evidences can support businesses to present a marketing viewpoint which not only manages satisfaction, rather it manages frustration and the methods through which complains can be handled (Plymire, 1991).

10 to 15 percent loss in the sale of the firm comes from customers who are dissatisfied because they communicate the negative experience to nine to ten different people. (TRAP, 1981) This explains the importance of identifying and responding to customer complaints.

From the Past research it is determined that in most circumstances, firms try their best to report the objections of the costumers who are not satisfied. Most of the top managerial staff is time and again ready to go above customer hopes and are motivated to respond to them (Resnik and Harmon, 1983).

As consumer's expectation have a direct relationship with company's profitability (Gurau and Ranchhod, 2002), company's struggle to eradicate such complaints from the customers truly give an indication of great business intellect. Unluckily, the number of complains does not measure the pleasure of the costumers correctly The reason is that most of the dissatisfied users might not protest (Best and Andreasen, 1977).Rather, the consumers who are not satisfied are likely to finish the bond or will remain silent with a confidence of getting things better (Hirschman, 1970, p. 38). The choice to complain or not to do it is conditional (Jacoby and Jaccard, 1981). For instance, a frustrated customer might not delay his schedule for an on-site supervisor, rather the customer would leave.

Traditionally the Complaints had been considered as negative reactions from frustrated customers and the efforts of the management were to stop and decrease these complains to the lowest level. But according to the latest research in the field of marketing negative reactions are considered as valuable feedback and essential signs of inadequate performance (Phau and Sari, 2004; Rizwan et al., 2013).

Another problem with products or services offered by the companies with customers that are dissatisfied is that they are inclined to keep quiet and turn towards competing businesses or express the undesirable experiences to their friends and relatives through informal channels 
of communication. The customer's relationship with the firm also matters a lot and a quiet a few number of consumers complain regarding their dissatisfaction about the products or services and request for improvement based on their association (Tschlo, 1994).

Such unplanned or inert complaining behavior indicates to much more sincere problems in company's enquiry to reach the actual reason of such discontent and the source of the problem, which leads to reduce chances of improving the buyer's dissatisfaction, and the recovery of service or product quality to win back the purchasers.

The purpose of this study is to examine the effect of attitude towards complaining, subjective norms and perceived possibility of success on complaining intention. While analyzing the variation caused by previous experience has upon these.

Attitude towards complaining can be defined as personal inclination of a certain dissatisfied consumer to look for return from the company.(Breadon and Mason, 1984) Achievements techniques and information which came us through the past cases (Singh and Wilkes. 1996).Perceived possibility of success can be explained as chance of receiving a compensation such as repayment exchanging the product or regret by complaining to a company.(Singh, 1990a).and subjective norms are the effect of peers, parents, siblings or love partners have on the intention to complain.

\section{Literature Review}

\subsection{Complaining intention}

A dissatisfied customer's intention in case of reporting complain to a company can be defined as customer's complaint intention. (Chulmin Kim, Sounghie Kim, Subin Im, Changhoon Shin, 2003). Intentions signify individual's inspiration in the way a person takes decision to put a particular struggle to act in a certain kind of behavior. Complaining intention consists of the following things: the individual's attitude towards a certain action; a common subjective norm to perform of a certain act; and the perceived possibility of getting the complaint successful.

This research particularly emphasis on the intention to complain rather than actual complaining behavior. Which has three main aims? Firstly, Chiu et al. (1988) said that the tendency to complain is the probability that consumers will record a complaint in a universal complaint condition with a certain level of displeasure; whereas complaint behavior by itself is a message of consumer's unhappiness with a certain product in a certain situation. Furthermore this type of behavior is fairly provisional, and dissimilar circumstances can lead to complaining or not complaining behavior. Secondarily, because of the complex kind of complaining behavior, real complaining behavior is tough to notice and estimate. The degree of such behavior is quite frequently observed by self-reports and the trustworthiness of such reports frequently endure from remembrance gaps (Singh, 1990; Phau and Sari, 2004; Rizwan et al., 2013). 
2.2. Attitude towards complaining

Attitude towards complaining can be defined as the optimistic or pessimistic evaluation of a certain conduct after evaluating the perceived consequences of an act by a particular person.( Fishbein and Ajzen,1975). Singh and Wilkes (1996) put forward the concept of attitude as overall feelings of the deed being good or bad of and not as a definite complaint . Pragmatic studies in both the field of psychological sciences and customer's behavior to complain consider it to be awkward or unpleasant .Contrarily, those who do not complain believe that reporting their discontent has no effect on the situation. Findings in the field of Behavioral studies revealed that an individual's attitude towards a particular conduct has a positive relation with the individual's behavioral intention (e.g., Kim et al., 2003).

The work done by Keng et al. (1995) conveyed that those persons who complain have much more positive attitude towards complaining as compared to individuals who do not complain. The individuals who complain might believe that it is their right to express in case if they are not satisfied with their buying's.

H1. There is a significant relationship between attitude towards complaining and intention to complain.

\subsection{Perceived possibility of Success}

Perceived possibility of a success can be conceptualized as particular decision by a costumer about the possibility of success in case the individual complains directly and receives the estimated benefit. Earlier studies proposed that, higher the apparent likelihood of a complain to be a success will rise the intention of the consumer to complain directly to the firm.

The perceived likelihood of getting a complaint successful can be conceptualized as, getting the required benefits while complaining directly to the firm .The customer's judgment here is subjective. Earlier studies proposed that as the perceived possibility of successful complaint increases the intention of customer to complain also increases.(Singh, 1989; Richens, 1987).

Perceived likelihood of successful complaint is also defined as the perceived chances of getting a return such as receiving the money back, to get the product replaced or service exchanged or getting an apology (Singh 1990a).

From the past research's it is clear that likelihood of successful complaint positively effects complaint intention.( Richins, 1983b, 1985, 1987; Singh 1990a, b)

When customers perceive that there complains are being accepted by the firms. They express their complaining feelings to the firm. On the other hand if they believe that the firm do not have interest in their complaints, they may think the complaints as unworthy they remain silent and never utilize the product/service.

H2. There is a significant relationship between perceived possibility of success and complaining intention. 


\subsection{Subjective Norms}

The degree to which an individual feels that "significant others" wants the person to act in the behavior in question (Fishbein and Ajzen, 1975). Significant other may include Parents, intimate friends, romance partners, bosses and personals from the business circle. Whenever an act is being carried out these norms put a social pressure on person's perception. From social psychology quite a number of studies have reported that behavioral intention of an individual can be calculated by his/her subjective norms. (Conner and Sparks, 1996).

H3. There is a significant relationship between subjective norms and intention to complain.

\subsection{Previous Experience}

Past Experience can be defined as techniques, information and communication skills achieved through the past related cases. Which may add up consumers positive attitude and confidence in the process of reporting complain and high hope is expected.(Lin Yin JIN, 2002). Consumers who complained repeatedly have much stronger believes and have much higher possibility of success then consumers who complain less often.

If loyal customers feel betrayed from a service failure they may react (Gre'goire and Fisher, 2008).From the above study we can conclude that attitude towards making complain is positively related with perceived possibility of making a successful complaint.

H4. There is a significant relationship between previous experience and attitude towards complaining.

H5. There is a significant relationship between previous experience and perceived possibility of success.

\section{Research Methodology:}

The nature of this research is descriptive. The explanation of descriptive research can be given as unfolding something, particular occurrence or any certain situation. In a descriptive research interpretation and judgments are not made rather they describe the existing situation.(Creswell, 1994). The primary objective in such type of research is to verify the developed hypothesis that reveals the present situation.

This kind of research provides information about the current development and emphasis on past or present for example quality of life in a community or customer attitudes towards any marketing activities (Kumar, 2005).

\subsection{Sample Data:}

The Data has been collected to understand the complaining intentions of Telecommunication users of Pakistan. A sample of 160 participants was asked to fill the self-administered questionnaire. Out of 160 questionnaires 150 complete questionnaires were used. 


\section{Macrothink}

International Journal of Learning \& Development

ISSN 2164-4063

2013, Vol. 3, No. 6

The population of the current research is Telecommunication users of Pakistan. Convenience sampling, a type of non-probability sampling technique is used in this study. It is a sampling technique which acquires and gathers the related information from the sample or of the study that are conveniently available (Zikmund, 1997). Normal usage of convenience sampling is collect huge number of completed surveys in a short time and low cost (Lym et al, 2010).It is ensured that the sample members frequently use Telecommunication services

\subsection{Instruments and Measures:}

The questions in questionnaire are built with help of previous researches. Initially questions are used to collect demographic and some basic information. This section of the questionnaire is used to obtain the respondent's information about gender, age, income and education.

This section includes the latent variables that are important in the current study. These variables includes Intention to complain, Attitude towards complaining, perceived possibility of success, previous experience and subjective norms

Other questions is shaped with 5-point Likert scale and designed as "strongly agree", "agree", "neutral", "disagree" and "strongly disagree" to measure the research variables.(Gursoy, McCleary and Lepsito (2007)'s

Table 1: $\quad$ Scales of the Study

\begin{tabular}{|c|c|c|c|}
\hline No & Variable & Items & Reference \\
\hline 1. & $\begin{array}{l}\text { Intention } \\
\text { to complain }\end{array}$ & $\begin{array}{l}\text { 1. I do not easily forget the unpleasant } \\
\text { problems without complaining or } \\
\text { protesting. } \\
\text { 2. I absolutely complain on site (or in the next } \\
\text { visit) to the staff or managers. } \\
\text { 3. I absolutely ask for problems solving on site } \\
\text { (or in the next visit). }\end{array}$ & $\begin{array}{l}\text { Singh1989 } \\
\text { (determinants of } \\
\text { customer } \\
\text { complaint } \\
\text { intention) }\end{array}$ \\
\hline 2. & $\begin{array}{l}\text { Possibility of } \\
\text { success with } \\
\text { the complaint }\end{array}$ & $\begin{array}{l}\text { 1. If you complain, the telecommunication } \\
\text { company would take the appropriate } \\
\text { measures to solve the problem. } \\
\text { 2. The telecommunication company would } \\
\text { solve the problem and offer you better } \\
\text { service in the future. } \\
\text { 3. The telecommunication company would } \\
\text { take greater care in the future to ensure that } \\
\text { customers are satisfied. }\end{array}$ & $\begin{array}{l}\text { Blodgett et al. } \\
(1993, \text { p. 414) }\end{array}$ \\
\hline
\end{tabular}




\begin{tabular}{|c|c|c|c|}
\hline 3. & $\begin{array}{l}\text { Subjective } \\
\text { Norms }\end{array}$ & $\begin{array}{l}\text { 1. My friends and family members think well } \\
\text { about complaining. } \\
\text { 2. The people around me perceive good about } \\
\text { complaining. }\end{array}$ & \\
\hline 4. & $\begin{array}{l}\text { Past } \\
\text { experience }\end{array}$ & $\begin{array}{l}\text { 1. You frequently complained to } \\
\text { telecommunication Company in the } \\
\text { previous year. } \\
\text { 2. You complained directly a lot to the } \\
\text { telecommunication companies. }\end{array}$ & $\begin{array}{l}\text { Blodgett et al. } \\
1993 \\
\text { (determinants of } \\
\text { customer } \\
\text { complaint } \\
\text { intention) }\end{array}$ \\
\hline 5. & $\begin{array}{l}\text { Attitude } \\
\text { towards } \\
\text { complaint }\end{array}$ & $\begin{array}{l}\text { 1. I feel uncomfortable, if complain directly } \\
\text { about dissatisfactory product or service to } \\
\text { the company. } \\
\text { 2. I feel obliged to complain directly about } \\
\text { dissatisfactory product or service to the } \\
\text { company. } \\
\text { 3. People should complain that much for it } \\
\text { happens(in reverse) } \\
\text { 4. It is necessary to ask for change or return, if } \\
\text { the failing product or service does not much } \\
\text { cost. } \\
\text { 5. When I have a problem with a product, even } \\
\text { if it is cheap, I usually complain, ask for a } \\
\text { refund or to change a product. } \\
\text { 6. Normally, I am reluctant to present a } \\
\text { complaint even if the product I have } \\
\text { purchased is no good/faulty. } \\
\text { 7. In general, I am more likely to complain, } \\
\text { ask for refund or to change the product than } \\
\text { other people I know. }\end{array}$ & $\begin{array}{l}\text { Adapted from } \\
\text { Blodgett et al. } \\
(1993, \text { p. } 414, \\
\text { 1997, p. 195) }\end{array}$ \\
\hline
\end{tabular}




\subsection{Procedure}

The questionnaire was distributed among 160 respondents in Bahawalpur city of Pakistan. These respondents are selected based on the criteria above mentioned. Before giving the questionnaire, the purpose of the study and questions were explained to the respondents so they can easily fill the questionnaire with relevant responses. A total of 160 questionnaires selected. After collecting, the completed questionnaires were coded and entered into SPSS sheet for further analysis.

\subsection{Reliability Analysis}

All the variables in research are reliable because the values of their Cronbach alphas is greater than 0.50 and 0.60 as recommended by Nunnally and Moss et al(1998) respectively.

Table 2: Reliability of Measurements Instrument

\begin{tabular}{|l|l|l|}
\hline Scales & Items & Cronbach Alpha \\
\hline Intention to Complain & 3 & 0.607 \\
\hline $\begin{array}{l}\text { Possibility of success with the } \\
\text { complaint }\end{array}$ & 3 & 0.654 \\
\hline Subjective Norms & 2 & 0.679 \\
\hline Past experience & 2 & 0.617 \\
\hline Attitude towards complaint & 7 & 0.746 \\
\hline
\end{tabular}




\section{A Macrothink \\ International Journal of Learning \& Development \\ ISSN 2164-4063 \\ 2013, Vol. 3, No. 6}

\section{Results and Analysis.}

\subsection{Profile of the Respondents}

Personal and demographic information of the respondents is presented in the following table.'

Table 3: Profile of the Respondents

\begin{tabular}{|c|c|c|c|}
\hline & Category & Frequency & Percentage \\
\hline \multicolumn{4}{|l|}{ Variable } \\
\hline Gender & $\begin{array}{c}\text { Male } \\
\text { Female }\end{array}$ & $\begin{array}{c}105 \\
45\end{array}$ & $\begin{array}{l}70.0 \\
30.0\end{array}$ \\
\hline Age & $\begin{array}{l}15-20 \\
20-25 \\
25-30 \\
30-35\end{array}$ & $\begin{array}{c}43 \\
103 \\
3 \\
1\end{array}$ & $\begin{array}{c}28.7 \\
68.7 \\
2.0 \\
0.7\end{array}$ \\
\hline Income & $\begin{array}{l}\text { Below } 15000 \\
15000-35000 \\
35000-40000 \\
\text { Above } 40000\end{array}$ & $\begin{array}{c}118 \\
22 \\
8 \\
2\end{array}$ & $\begin{array}{c}78.7 \\
14.7 \\
5.3 \\
1.3\end{array}$ \\
\hline Education & $\begin{array}{c}\text { Intermediate } \\
\text { Bachelor } \\
\text { Master } \\
\text { MS }\end{array}$ & $\begin{array}{c}3 \\
99 \\
32 \\
32 \\
16\end{array}$ & $\begin{array}{c}2.0 \\
66.0 \\
21.3 \\
10.7\end{array}$ \\
\hline Status & $\begin{array}{c}\text { Student } \\
\text { Employed } \\
\text { Unemployed } \\
\text { Housewife } \\
\text { Businessman }\end{array}$ & $\begin{array}{c}140 \\
5 \\
3 \\
1 \\
1\end{array}$ & $\begin{array}{l}93.3 \\
3.3 \\
2.0 \\
0.7 \\
0.7\end{array}$ \\
\hline Telecommunication & $\begin{array}{l}\text { Mobilink } \\
\text { Ufone } \\
\text { Warid } \\
\text { Telenor } \\
\text { Zong }\end{array}$ & $\begin{array}{c}44 \\
62 \\
6 \\
22 \\
16\end{array}$ & $\begin{array}{c}29.3 \\
41.3 \\
4.0 \\
14.7 \\
10.7\end{array}$ \\
\hline
\end{tabular}




\subsection{Hypothesis Testing}

\subsubsection{Attitude towards complaining, Complaining Intention}

The results from the regression analysis of this study tells that attitude towards complaining has a significant positive relationship with $(\beta=0.230)$ and $(\mathrm{p}<0.011)$. The results propose that attitude towards complaining almost has more impact on complaining intention as compared to perceived possibility of success. The outcome of this study supports H3.

\subsubsection{Perceived Possibility of success, Complaining Intention}

The regression results of this study confirm the significant positive relationship between perceived possibility of success and complaining intention with $(\beta=0.109)$ and $(p<0.023)$.

According to these results, perceived possibility of success has more than $10 \%$ effect on complaining intention. So the result of the study supports H4.

\subsubsection{Subjective Norms, Complaining Intention}

There is a significant positive relationship between subjective norms and complaining intention with $(\beta=0.123)$ and $(p<0.033)$.it means subjective norms contribute more than $12 \%$ to complaining intention. So $\mathrm{H} 5$ is valid

\subsubsection{Previous experience, Attitude towards complaining}

According to the outcomes of this study, the variable of previous experience has a significant positive relationship with attitude towards complaining. Precisely, this variable has a significant positive relationship with $(\beta=0.300)$ and $(\mathrm{p}<.000)$. We come to know that previous experience contributes $30 \%$ to attitude towards complaining. Results of the current study validate the $\mathrm{H} 1$.

\subsubsection{Previous experience, Perceived possibility of success}

The regression results of the current study confirm the significant positive relationship between previous experience and perceived possibility of success with $(\beta=0.178)$ and $(p<0.029)$. According to the results, previous experience adds $17 \%$ to perceived possibility of success. This result of study validates $\mathrm{H} 2$.

\section{Table: Regression Results}

\begin{tabular}{|c|c|c|c|c|c|c|}
\hline $\begin{array}{l}\text { Hypoth } \\
\text { esis }\end{array}$ & Model Variables & Estimate & S.E. & C.R. & $\mathbf{P}$ & Results \\
\hline H1 & $\begin{array}{l}\text { ATC } \longrightarrow \\
\text { CI }\end{array}$ & 0.230 & 0.118 & 2.564 & 0.011 & supported \\
\hline H2 & $\begin{array}{l}\text { PPS } \longrightarrow \\
\text { CI }\end{array}$ & 0.109 & 0.088 & 2.224 & 0.023 & supported \\
\hline
\end{tabular}




\begin{tabular}{|l|l|l|l|l|l|l|}
\hline H3 & $\begin{array}{l}\text { SN } \\
\text { CI }\end{array}$ & 0.123 & 0.086 & 1.840 & 0.033 & supported \\
\hline H4 & $\begin{array}{l}\text { PE } \\
\text { ATC }\end{array}$ & 0.300 & 0.045 & 3.829 & 0.000 & supported \\
\hline H5 & $\begin{array}{l}\text { PE } \\
\text { PPS }\end{array}$ & 0.178 & 0.058 & 2.205 & 0.029 & supported \\
\hline
\end{tabular}

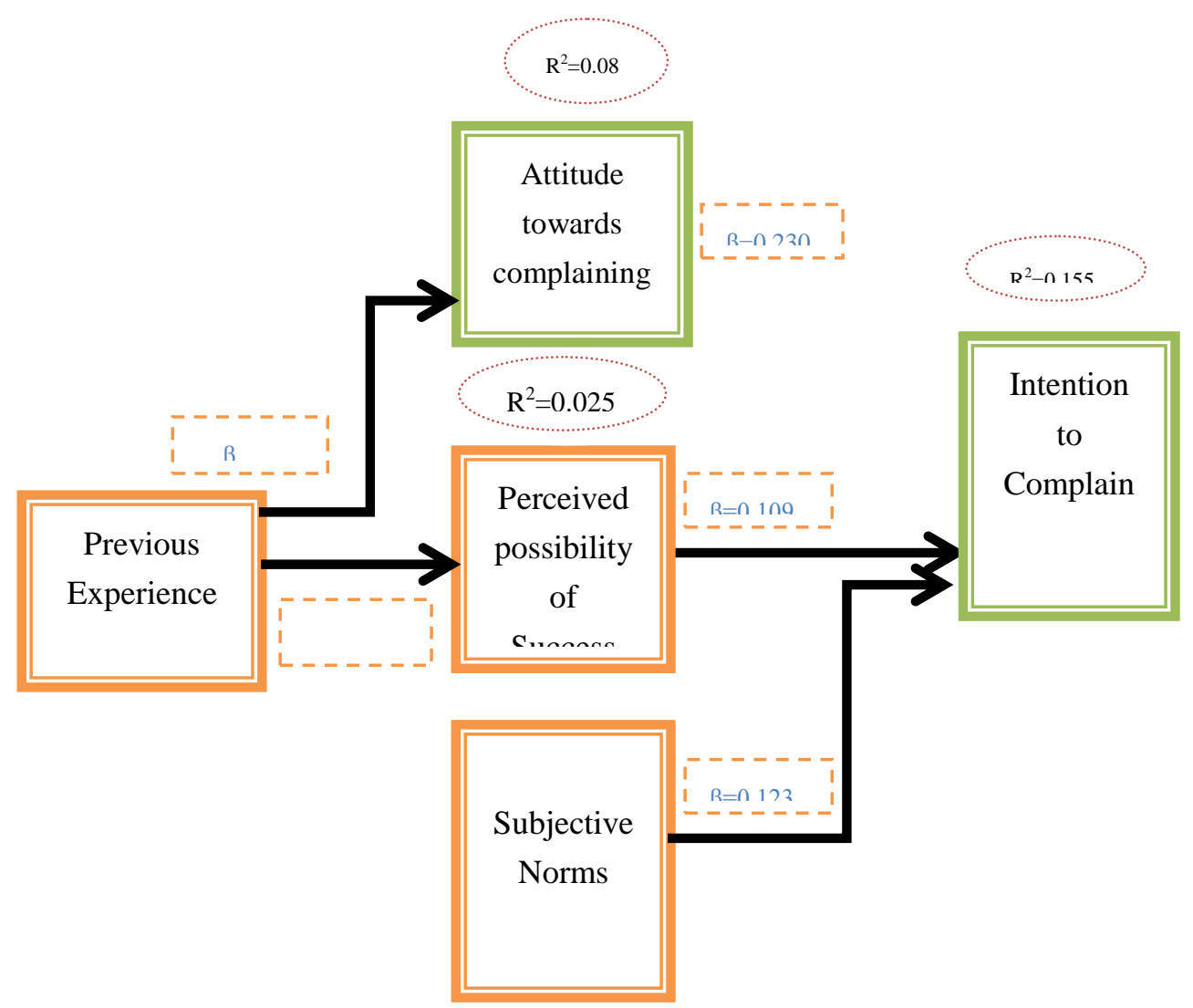




\section{Discussion}

By making sure that consumers convey their dissatisfactions to firm factors that lead to customer's discontent can be depicted and eliminated with which the firm can reach both its economic and social goals. Organizations which know the reasons and situations that lead the costumers to express their utilization related problems to firm and take essential safety measures by considering such information can decrease and possibility of potential problems ,consumer losses and unpleasant behaviors' of frustrated consumers .

The research focuses on telecommunications firms' complaint intention. The customers with the previous experience of complaint develop a more positive attitude towards complaining and hence they intend to complain more due to which the possibility of dissatisfaction can be decreased. 'The degree of previous complaining experiences can lead a customer's attitudinal and behavioral nature's in the future situations (Singh and Wilkes.1996: Ursic, 1985a, b). Previous complaint experience can influence attitude towards complaining as costumers learn about the methods, options ways and positive outcomes of previous complaint process, they develop more positive attitude towards complaining.(Singh andWikles,1996).

The perception of a possible outcome needs to be improved so that the customers are encouraged to complain directly to the firm. Different operational practices can be used such as providing warranties and guaranties for the concerned product/service. By adding more functions in the customer service centers, by adding complain registers/records and by showing customers what have been improved about regarding their complains.

The attitude towards complaining has a connection with behavioral intention, In general the consumers with a positive attitude towards complain will have much more tendency to complain (Grace and Bodey, 2007; Blodgett et al. 1995; Crockett and Bearden, 1981)Past studies of consumer complaint behavior give us an idea of protest against dissatisfaction (Singh, 1989; Wilkes and Singh, 1996).here "protest against dissatisfaction" can be a explained as a way to express the protest and ask for process about compensation to avoid dissatisfaction .The relationship between past experience and attitude has been given by (singh and Wikes,1996).According to them the people who have the knowledge of past know the criteria will be encouraged to complain more.

In short from the results we can conclude that previous experience has very significant and positive effect on Attitude towards complaint as the $\beta=0.300$. This means that if a person has previous experience he develops a more positive attitude towards complaining. Furthermore previous experience has significant and positive relation on perceived possibility of success but less intense than attitude towards complaining. This means that a person with previous experience thinks that there are more chances of getting the complaint successful.

Complaining intention is significantly and positively $(\beta=0.23)$ affected by attitude towards complaining this means that if an individual has positive attitude towards complaining it is more likely that a person intends to complain rather than switching or spreading negative word of mouth.

Complaining intention is also significantly and positively connected $(\beta=0.109)$ with 


\section{Al Macrothink}

International Journal of Learning \& Development

ISSN 2164-4063

2013, Vol. 3, No. 6

perceived possibility of success. If person perceives that his complain will be successful he is more likely to complain.

The family, friends and business partners are a part of subjective norms they opinion is also keen and significant. This factor should also be kept in mind during the policy making activities.

\section{Limitations and Future Research}

The sample has been collected mainly from the persons below the age of 25 other age groups should also be considered. Main occupation of the sample was students other occupations especially businessman and job oriented people must also be considered. The sample has more male respondents. Only one type of analysis that is regression analysis has been done other type of analysis should also be considered to improve the results further.

The data was mainly collected from a small town of Bahawalpur and only collected from urban areas. Other cities and rural areas should also be considered in order to get better results.

\section{Managerial Implications}

The research can be a starting point to manage the complain of the customers and concentrate on factors mentioned in the research. The research gives a deep insight to managers of telecommunication firms in south asia and specially in Pakistan. The results in this research can be utilized to improve their performance.

\section{References}

Bearden.W.O. and Mason.J.B(1984)"An investigation of influences on consumer complaint reports" . In Kinnear T.C (ED.), Advances in Consumer Research .Vol. 11. Association of consumer Research. Provo.UT.pp. 490-5

Best, A. and Andreasen, A.R. (1977), "Consumer response to unsatisfactory purchases: a survey of perceiving defects, voicing complaints, and obtaining redress", Law \& Society, Vol. 11, pp. 701-42

Blodgett, J.G., Granbois, D.H. and Walters, R.G. (1993), "The effects of perceived justice on complaint's negative word-of-mouth behavior and repatronage intensions" , Journal of Retailing, Vol. 69, Winter, pp. 399-428.

Blodgett, J.G., Hill, D.J. and Tax, S.S. (1997), "The effects of distributive, Procedural, and interactional justice on post complaining behavior", Journal of Retailing, Vol. 73 No.2, pp. 185-210.

Chiu, C.Y., Tsang, S.C., Yang, C.F., 1988.The role of face situation and attitudinal antecedents in Chinese consumer complaint behavior. The Journal of Social Psychology 128 (2), 173-180. 


\section{Macrothink}

International Journal of Learning \& Development

ISSN 2164-4063

2013, Vol. 3, No. 6

Conner, M., Sparks, P., 1996.The theory of planned behavior and health behaviors. In: Conner, M., Norman, P. (Eds.), Predicting Health Behavior Buckingham. Open University Press, UK, pp. 121-162.

Chulmin Kim, Sounghie Kim, Subin Im, Changhoon Shin, (2003), "The effect of attitude and perception on consumer complaint intentions", Journal of consumer Marketing, Vol. 20 Iss: 4pp. 352-371

Day, R., Grabickle, K., Schaetzle, T. and Staubauch, F.(1981), "The hidden agenda of consumer complaining”, Journal of Retailing, Vol. 57 No. 3, pp. 86-106.

Fishbein, M., Ajzen, I., 1975.Belief, Attitude, Intention, and Behavior. An Introduction to Theory and Research. Addison-Wesley, MA.

Gurau, C. and Ranchhod, A. (2002), "How to calculate the value of a customer - measuring customer satisfaction: a platform for calculating, predicting and increasing customer profitability", Journal of Targeting, Measurement, and Analysis for Marketing, Vol. 10 No. 3, pp. 203-19.

Hirschman, A. (1970), Exit, Voice, and Loyalty: Responses to Declines in Firms, Organizations, and States, Harvard University Press, Cambridge, MA.

Hupperts, J.W. (2003), “An effort model of first-stage complaining behavior”, Journal of Consumer Satisfaction, Dissatisfaction, and Complaining Behavior, Vol. 16,pp. 132-44.

Jacoby, J. and Jaccard, J.J. (1981), "The sources, meaning, and validity of consumer complaint behavior: a psychological analysis", Journal of Retailing, Vol. 57 No. 3, pp. 4-24.

Keng, K.A., Richmond, D., Han, S., 1995. Determinants of consumer complaint behavior: a study of Singapore consumers. Journal of International Consumer Marketing 8 (2), 59-76.

Kim, C., Kim, S., Im, S., Shin, C.H., 2003. The effect of attitude and perception on consumer complaint intentions. Journal of Consumer Marketing 20 (4), 352-371.

Phau, I. and Sari, R.P. (2004), "Engaging in complaint behavior: an Indonesian perspective", Marketing Intelligence \& Planning, Vol. 22 No. 4, p. 407.

Phau, I., Sari, R.P., 2004. Engaging in complaint behavior: an Indonesian perspective. Marketing Intelligence and Planning 22 (4), 407-426.

Plymire, J. (1991), “Complaints as opportunities”, Journal of Consumer Marketing, Vol. 8 No. 2, pp. 39-43.

Resnik, A.J. and Harmon, R.R. (1983), "Consumer complaints and managerial response: a holistic approach”, Journal of Marketing, Vol. 47 No. 1, pp. 86-97

Rizwan, M., Khan, A., Saeed, I., Shah, K., Azhar, N. \& Anam, W. (2013) Determinants of Customer Complaining Behavior, International Journal of Research in Computer Applications and Management, 3(3), 119-124

Richins, M.L. (1987), “A multi variate analysis of responses to dissatisfaction”, Journal of the 
Academy of Marketing Science, Vol. 15, Fall, pp. 24-31.

Rizwan, M., Athar, M. A., Waheed, M., Waheed, Z., Imtiaz, R. \& Munir, A. (2013) Recognizing Customer Complaint Behavior in Resturants, International Journal of Research in Commerce, IT and Management, 3(3), 116-122

Richins, M.L. and Verhage, B.J. (1985), "Seeking redress for consumer dissatisfaction: the role of attitudes and situational factors", Journal of Consumer Policy, Vol. 8 No. 1, pp. 29-44.

Singh, J. (1989). "Determinants of consumers' decisions to seek third party redress: an empirical study of dissatisfied patients", Journal of consumer affairs, Vol.23, Winter,

Singh, J. (1990a), "Voice, exit and negative word-of mouth behaviors: an investigation across three service categories", Journal of the Academy of Marketing Science, Vol. 18 No. 1,pp. $1-15$.

Singh, J. (1990b), "A typology of consumer dissatisfaction response style”, Journal of Retailing,Vol. 66 No. 1, pp. 57-99.

Singh, J. and Wilkes, R.E. (1996), "When consumers complain: a path analysis of the key antecedents of consumer complaint response estimates", Journal of the Academy of Marketing Science, Vol. 24 No. 4, pp. 350-65.

Singh, J., 1990. Identifying consumer dissatisfaction response styles: an agenda for future research. European Journal of Marketing 24 (6),55-72.

Singh, J., Wilkes, P.E., 1996. When consumers complain: a path analysis of the key antecedents of consumer complaint response estimates. Journal of the Academy of Marketing Science 24 (4),350-365.

Technical Assistance Research Programs (TARP) (1981), Measuring the Grapevine Consumer Response and Word-of-Mouth, US Office of Consumer Affairs, Washington DC

Tschlo, J. (1994), "Do yourself a favor: gripe about bad service", The American Salesman, Vol. 39,pp. 3-5.

Ursic, M. (1985a), "Consumer use of the legal redress system:” , Southern Marketing Association proceedings, pp. 273-5.

Ursic, M. (1985b), "A model of the consumer decision to seek legal redress". Journal of Consumer Affairs, Vol. 19, pp. 20-35.

Yeung, M.C.H., Ging, L.C. and Ennew, C.T. (2002), "Customer satisfaction and profitability: a reappraisal of the nature of the relationship", Journal of Targeting, Measurement, and Analysis for Marketing, Vol. 11 No. 1,pp. 24-33.

Zeelenberg, M. and Pieters, R. (2004), "Beyond valence in customer dissatisfaction: a review and new findings on behavioral responses to regret and disappointment in failed services", Journal of Business Research, Vol. 57 No. 4,pp. 445-55. 